HortSCIENCE 26(7):890-891. 1991.

\title{
Low Oxygen Delays Budbreak of Apple Trees in Greenhouse and Prolongs Storage Life
}

\author{
Eric Young and S.M. Blankenship ${ }^{2}$ \\ Department of Horticultural Science, North Carolina State University, \\ Raleigh, NC 27695 \\ Additional index words. Malus domestica, dormancy, controlled atmosphere, nursery \\ stock, postharvest handling
}

\begin{abstract}
Three percent oxygen significantly delayed and reduced budbreak of fully chilled apple (Malus domestica Borkh.) trees in a greenhouse. When ambient oxygen levels were restored, budbreak occurred normally. Apple trees stored under $3 \% \pm$ $1 \%$ oxygen at $6 \mathrm{C}$ for 35 weeks had no detectable bud development in storage. Budbreak and subsequent shoot growth were normal after the trees had been removed from storage.
\end{abstract}

A significant rise in respiration in apple shoot and root tissue has been associated with the completion of chilling and renewed growth (Young, 1990). We found no studies on the effects of suppressing this respiration increase on dormancy release. Low-oxygen atmospheres decrease respiration in plant tissue and delay ripening, the basis for low-oxygen storage of fruits (Smock, 1979). However, we found no work on low-oxygen storage of trees. Anaerobic conditions and the resulting anaerobic respiration may be involved in overcoming bud dormancy in trees (Samish, 1954). Low-oxygen $(<5 \%)$ conditions imposed after completing $70 \%$ of the chilling

Received for publication 9 May 1990. The research reported in this publication was funded by the North Carolina Agricultural Research Service. The cost of publishing this paper was defrayed in part by the payment of page charges. Under postal regulations, this paper therefore must be hereby marked advertisement solely to indicate this fact. 'Professor.

${ }^{2}$ Associate Professor. requirement enhanced budbreak of peach trees (Erez et al., 1980). The purpose of our study was to investigate the influence of an atmosphere with a lower than normal oxygen concentration on budbreak of fully chilled trees.

One-year-old 'Starkspur Supreme Delicious' on seedling rootstock from a commercial nursery were pruned to a single shoot. All studies were initiated in March after chilling completion ( $\approx 1500$ chill units). Trees were chilled in a room at $6 \mathrm{C}$, with moist peat moss around the bare roots; the whole bundle was wrapped loosely in plastic to avoid desiccation. For the first two studies, trees were potted in calcined clay (Turface) in 3.5liter containers. For the third study, trees remained bare-root and wrapped as they were during chilling. Trees were watered with a one-half strength Hoagland's (Hoagland, 1950) solution when the root medium surface appeared dry.

Low-oxygen effects on budbreak were examined in three separate studies, each using the trees described above. The first two stud- 


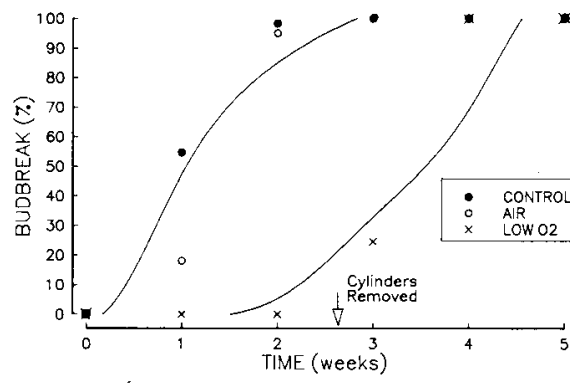

Fig. 1. Budbreak on fully chilled apple shoots under either low oxygen $(3 \% \pm 1 \%)$ and 350 $\mu \mathrm{l} \mathrm{CO}_{2} /$ liter or ambient air in a greenhouse at $23 \pm 2 \mathrm{C}$. Each data point represents the mean of 10 replications. Control and air: budbreak = $-2.5+57.6$ (time) -7.6 (time) $)^{2}, R^{2}=0.68$, $P=0.01$; low oxygen: budbreak $=-3.5-$ 3.3 (time) $+5.4(\text { time })^{2}, R^{2}=0.71, P=0.04$.

ies involved enclosing the entire intact shoot in a 2.3-liter clear plexiglass cylinder sealed at the top and placed over the shoot. The bottom was closed using a neoprene rubber gasket with a small center hole for the shoot and a hose clamp to seal the rubber to the cylinder. The elastic neoprene rubber provided a very tight seal around the shoot. Lowoxygen atmospheres were obtained by flowing a humidified mixture of $3 \% \pm 1 \%$ oxygen plus $350 \mu \mathrm{C} \mathrm{CO}_{2} /$ liter, with the balance $\mathrm{N}$, through the cylinders at $50 \mathrm{ml} \cdot \mathrm{min}^{-1}$. Gas samples taken periodically through a septum in the side of the cylinder showed the flow rate was sufficient to maintain oxygen and $\mathrm{CO}_{2}$ concentrations at the input levels. The third study involved sealing entire trees in 212-liter drums and flowing either ambient air or the same low-oxygen mixture at 10 to $20 \mathrm{ml} \cdot \mathrm{min}^{-1}$ through the drum. Gas samples taken weekly from the drums indicated that oxygen did not rise above $5 \%$ and $\mathrm{CO}_{2}$ above $500 \mu \mathrm{l} \cdot$ liter $^{-1}$. Each study used 10 wholetree replicates for each treatment in a completely randomized design.

In the first study, trees were placed in a $23 \pm 2 \mathrm{C}$ greenhouse and assigned to one of three treatments: 1) entire shoot open to the air, 2) shoot enclosed with ambient air flowing through, or 3) shoot enclosed the lowoxygen atmosphere flowing through. Air temperature was monitored inside the cylinders and never exceeded 2C above ambient. Treatments were maintained for 3 weeks, at which time the cylinders were removed. Budbreak was monitored weekly for 5 weeks following initiation of the gas treatments and percent budbreak calculated each time.

In the second study, trees were placed in the same greenhouse and assigned to one of three treatments: 1) entire shoot exposed to air, 2) entire shoot exposed to $3 \% \mathrm{O}_{2}$, or 3 ) top half of the shoot exposed to $3 \% \mathrm{O}_{2}$ and bottom half left exposed to air. Treatments were maintained for 7 weeks, at which time the cylinders were removed. Budbreak was monitored weekly on each half-shoot section

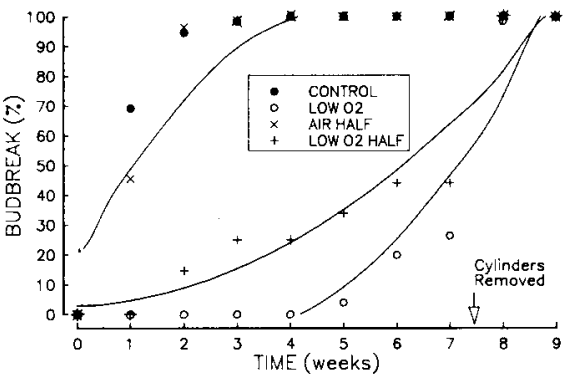

Fig. 2. Budbreak on fully chilled apple shoots under either low oxygen $(3 \% \pm 1 \%)$ and 350 $\mu \mathrm{CO}_{2} /$ liter or ambient air in a greenhouse at $23 \pm 2$ C. Low-oxygen half $=$ upper half of shoots enclosed in a low-oxygen atmosphere; air half = lower half of the same trees exposed to ambient air. Each data point represents the mean of 10 replications. Control and air half: budbreak $=21.0+30.5($ time $)-2.6(\text { time })^{2}$, $R^{2}=0.67, P=0.01$; low-oxygen: budbreak $=7.8-12.9$ (time) $+2.7(\text { time })^{2}, R^{2}=0.87$, $P=0.01$; low-oxygen half: budbreak $=2.8$ $+0.8($ time $)+1.1(\text { time })^{2}, R^{2}=0.89, P=$ 0.01 .

for 9 weeks after initiation of gas treatments and percent budbreak calculated each time.

In the third study, the trees in the drums were placed in a room at $6 \pm 2 \mathrm{C}$ with either ambient air or the low-oxygen moisture flowing through as described above. Treatments were maintained for 35 weeks, at which time trees were removed from the drums, potted in calcined clay in 3.5-liter containers, and placed in a greenhouse at $23 \pm$ $2 \mathrm{C}$ for 5 weeks. Budbreak was monitored weekly beginning when trees were placed in the greenhouse and percent budbreak was calculated. All percentage data were transformed by the arcsin of the square root before analysis. Budbreak data from all studies were subjected to analysis of variance and regression using SAS General Linear Models procedure (SAS Institute, Cary, N.C.).

There was no significant difference in budbreak between the trees open to ambient air and those enclosed in cylinders with ambient air flowing through (Fig. 1), therefore, these data points were combined for regression analysis. Budbreak of trees in the greenhouse with shoots enclosed in a low-oxygen atmosphere was delayed 3 to 4 weeks relative to the controls (Figs. 1 and 2), Budbreak occurred normally after return of the shoots to air, and final budbreak was similar to that of the controls (Figs. 1 and 2). Where the shoot was divided, budbreak of the half in air was similar to that of the control; thus, these data were combined for regression analysis (Fig. 2). The half in low oxygen had limited budbreak, but it started earlier than for the shoot totally under low oxygen. Whether this difference indicates that a stimulus from the air half had been translocated upward or some oxygen diffused upward through the shoot is unknown. When the cylinders were removed, the low-oxygen half underwent rapid budbreak, resulting in the

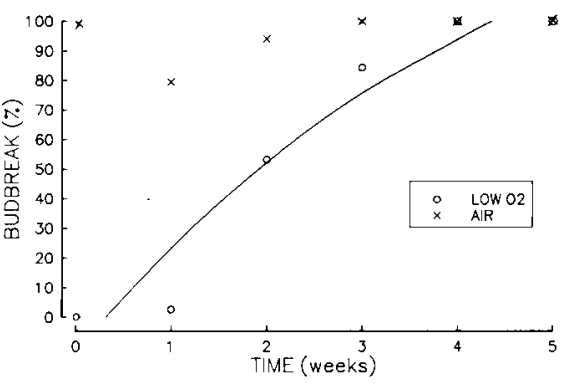

Fig. 3. Budbreak of apple trees stored 35 weeks in either low oxygen $(3 \% \pm 1 \%)$ and $350 \mu \mathrm{l}$ $\mathrm{CO}_{2} /$ liter or ambient air at $6 \mathrm{C}$ and then placed in a greenhouse at $23 \pm 2 \mathrm{C}$. Each data point represents the mean of 10 replications. Air: nonsignificant; low oxygen: budbreak $=-11.2$ +37.2 ( time) -2.7 (time $)^{2}, R^{2}=0.78, P=$ 0.02 .

entire shoot of this treatment resembling the controls.

When trees in study 3 were removed from the drums, those from low oxygen had no budbreak or swelling evident, while the airstored trees had significant budbreak (Fig. 3) and small, etiolated shoots. When placed in the greenhouse, the air-stored trees had an average of one new shoot per tree, which died and abscised within 1 week. Other shoots emerged, developed chlorophyll, and began to elongate. These trees had one or two buds break within 3 weeks (Fig. 3). Following removal from the drums, trees that had been held under low oxygen underwent normal budbreak, reaching the air-stored level within 3 weeks.

Under normal shipping and field planting conditions, the etiolated shoots on the airstored trees might not have survived, possibly making these trees unacceptable for orchard use. However, the low-oxygen stored trees appeared to be as dormant as when put into storage and presumably would have survived much better. These results indicate that a low-oxygen atmosphere $(3.0 \%)$ applied after chilling strongly inhibits budbreak in apple without detrimental effects. Also, when low oxygen is combined with low temperature (6C), apple budbreak may be inhibited completely for at least 35 weeks.

\section{Literature Cited}

Erez, A., G.A. Couvillon, and S.J, Kays. 1980. The effect of oxygen concentration on the release of peach leaf buds from rest. HortScience 15:39-41.

Hoagland, D.R. and D.I. Arnon. 1950. The waterculture method for growing plants without soil. Calif. Agr. Expt. Sta., Circ. no. 347:1-32.

Samish, R.M. 1954. Dormany in woody plants. Annu. Rev. Plant Physiol. 5:183-204.

Smock, R.M. 1979. Controlled atmosphere storage of fruits. Hort. Rev. 1:301-336.

Young, E. 1990. Changes in respiration rate and energy of activation after chilling and forcing dormant apple trees. J. Amer. Soc. Hort. Sci. 115:809-814. 